\title{
Front Matter: Volume 7046
}

, "Front Matter: Volume 7046," Proc. SPIE 7046, Optical Modeling and Measurements for Solar Energy Systems II, 704601 (2 October 2008); doi: 10.1117/12.814691

SPIE Event: Solar Energy + Applications, 2008, San Diego, California, United SPIE. States 


\section{PROCEEDINGS OF SPIE}

\section{Optical Modeling and Measurements for Solar Energy Systems II}

Benjamin K. Tsai

Editor

13-14 August 2008

San Diego, California, USA

Sponsored and Published by

SPIE 
The papers included in this volume were part of the technical conference cited on the cover and title page. Papers were selected and subject to review by the editors and conference program committee. Some conference presentations may not be available for publication. The papers published in these proceedings reflect the work and thoughts of the authors and are published herein as submitted. The publisher is not responsible for the validity of the information or for any outcomes resulting from reliance thereon.

Please use the following format to cite material from this book:

Author(s), "Title of Paper," in Optical Modeling and Measurements for Solar Energy Systems II, edited by Benjamin K. Tsai, Proceedings of SPIE Vol. 7046 (SPIE, Bellingham, WA, 2008) Article CID Number.

ISSN 0277-786X

ISBN 9780819472663

Published by

SPIE

P.O. Box 10, Bellingham, Washington 98227-0010 USA

Telephone +1 3606763290 (Pacific Time) · Fax +1 3606471445

SPIE.org

Copyright (C 2008, Society of Photo-Optical Instrumentation Engineers

Copying of material in this book for internal or personal use, or for the internal or personal use of specific clients, beyond the fair use provisions granted by the U.S. Copyright Law is authorized by SPIE subject to payment of copying fees. The Transactional Reporting Service base fee for this volume is $\$ 18.00$ per article (or portion thereof), which should be paid directly to the Copyright Clearance Center (CCC), 222 Rosewood Drive, Danvers, MA 01923. Payment may also be made electronically through CCC Online at copyright.com. Other copying for republication, resale, advertising or promotion, or any form of systematic or multiple reproduction of any material in this book is prohibited except with permission in writing from the publisher. The CCC fee code is $0277-786 \mathrm{X} / 08 / \$ 18.00$.

Printed in the United States of America.

Publication of record for individual papers is online in the SPIE Digital Library.

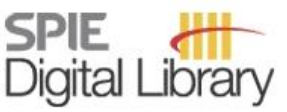

SPIEDigitallibrary.org

Paper Numbering: Proceedings of SPIE follow an e-First publication model, with papers published first online and then in print and on CD-ROM. Papers are published as they are submitted and meet publication criteria. A unique, consistent, permanent citation identifier (CID) number is assigned to each article at the time of the first publication. Utilization of CIDs allows articles to be fully citable as soon they are published online, and connects the same identifier to all online, print, and electronic versions of the publication. SPIE uses a six-digit CID article numbering system in which:

- The first four digits correspond to the SPIE volume number.

- The last two digits indicate publication order within the volume using a Base 36 numbering system employing both numerals and letters. These two-number sets start with 00, 01, 02, 03, 04, 05, $06,07,08,09,0 A, 0 B \ldots 0 Z$, followed by $10-12,20-2 Z$, etc.

The CID number appears on each page of the manuscript. The complete citation is used on the first page, and an abbreviated version on subsequent pages. Numbers in the index correspond to the last two digits of the six-digit CID number. 


\section{Contents}

$\checkmark$ Conference Committee

vii Introduction

ix Commercialization of large scale CPV: What lies ahead? (Plenary Paper) [7043-104]

D. Holland, Solar Systems Pty. Ltd. (Australia)

xv Nanostructures for high-efficiency photovoltaics (Plenary Paper) [7047-102]

H. A. Atwater, California Institute of Technology (United States)

xix Reliability of PV systems (Plenary Paper) [7048-101]

J. H. Wohlgemuth, BP Solar International Inc. (United States)

SESSION 1 CELLS AND SYSTEMS MODELING AND MEASUREMENT I

704603 Prediction of solar global radiation on a surface tilted to the south [7046-18]

A. I. Kudish, E. G. Evseev, Ben-Gurion Univ. of the Negev (Israel)

704604 Spectral optimization of CPV for integrated energy output [7046-01]

M. McDonald, C. Barnes, SolFocus, Inc. (United States)

$704605 \quad$ High-throughput photovoltaic cell characterization system [7046-02]

V. Kochergin, Z. Shi, K. Dobson, Luna Innovations Inc. (United States)

704607 Optical modeling of nanostructured films for selective coatings [7046-05]

P. P. Altermatt, Univ. of Hannover (Germany) and Institute for Solar Energy Research

Hamelin (Germany); Y. Yang, Institute for Solar Energy Research Hamelin (Germany) and Sun Yat-Sen Univ. (China); J. Wang, R. Reineke-Koch, F. Giovannetti, Institute for Solar Energy Research Hamelin (Germany)

704608 Microstructured anti-reflection surface design for the omni-directional solar cells [7046-03]

L. Chen, H. Yang, M. Tao, W. Zhou, The Univ. of Texas at Arlington (United States)

\section{SESSION 2 CELLS AND SYSTEMS MODELING AND MEASUREMENT II}

704609 Monte Carlo simulations of quantum dot solar concentrators: ray tracing based on fluorescence mapping [7046-06]

A. Schüler, A. Kostro, B. Huriet, C. Galande, J.-L. Scartezzini, Ecole Polytechnique Fédérale de Lausanne (Switzerland)

7046 OA Synthesis and optical characterization of C-SiO ${ }_{2}$ and $\mathrm{C}$-NiO sol-gel composite films for use as selective solar absorbers [7046-07]

G. Makiwa, Univ. of Zimbabwe (Zimbabwe); G. Katumba, Council for Scientific and Industrial Research (South Africa); L. Olumekor, Univ. of Zimbabwe (Zimbabwe) 
7046 OB Quantifying the efficacy of solar selective absorber materials: the case of carbon nanoparticles dispersed in $\mathrm{SiO}_{2}, \mathrm{ZnO}$, and NiO matrices [7046-08]

G. Katumba, Council for Scientific and Industrial Research (South Africa); A. Forbes, Council for Scientific and Industrial Research (South Africa) and Univ. of KwaZulu-Natal

(South Africa); L. Olumekor, G. Makiwa, Univ. of Zimbabwe (Zimbabwe)

\section{SESSION 3 SOLAR RESOURCES MODELING AND MEASUREMENT I}

7046 OC Modeling energy production for concentrating PV flat panel [7046-10]

B. Chang, SV Solar (United States)

7046 OD Fixed or tracking solar collectors? Helping the decision process with the Solar Resource Enhancement Factor [7046-11]

C. A. Gueymard, Solar Consulting Services (United States)

7046 OE Modeling IR radiative loss from Eppley PSP pyranometers [7046-14]

F. Vignola, Univ. of Oregon (United States); C. Long, Pacific Northwest National Lab. (United States); I. Reda, National Renewable Energy Lab. (United States)

\section{SESSION 4 SOLAR RESOURCES MODELING AND MEASUREMENT II}

7046 OF Corrections for rotating shadowband pyranometers for solar resource assessment [7046-15] N. Geuder, Deutsches Zentrum für Luft- und Raumfahrt e.V. (Germany); B. Pulvermüller, Solar Millennium AG (Germany); O. Vorbrugg, Flagsol GmbH (Germany)

POSTER SESSION

7046 ol Pulse analysis spectroradiometer system for measuring the spectral distribution of flash solar simulators [7046-20]

A. M. Andreas, D. R. Myers, National Renewable Energy Lab. (United States)

7046 0J Shape and alignment measurement of the heliostat by laser deflectometry [7046-21] W. Xu, Changchun Institute of Optics, Fine Mechanics and Physics (China) and Graduate School of the Chinese Academy of Sciences (China); Z. Lu, H. Liu, H. Zhang, Changchun Institute of Optics, Fine Mechanics and Physics (China); Z. Ni, Aviation Univ. of Air Force (China)

7046 OM Indoor characterization of photovoltaic modules under various conditions [7046-24] M. Zettl, O. Stern, O. Mayer, M. Hartung, M. Lynass, E. Bernal, GE Global Research Europe (Germany)

Author Index 


\title{
Conference Committee
}

\author{
Symposium Chair \\ Ravi Durvasula, Lightfleet Corporation (United States) \\ Conference Chair
}

Benjamin K. Tsai, National Institute of Standards and Technology (United States)

Program Committee

Jorge Gonzalez, Santa Clara University (United States)

Christian A. Gueymard, Solar Consulting Services (United States)

Daryl R. Myers, National Renewable Energy Laboratory (United States)

Govindasamy TamizhMani, Arizona State University (United States)

Frank E. Vignola, University of Oregon (United States)

Session Chairs

1 Cells and Systems Modeling and Measurement I

Frank E. Vignola, University of Oregon (United States)

2 Cells and Systems Modeling and Measurement II

Frank E. Vignola, University of Oregon (United States)

3 Solar Resources Modeling and Measurement I

Christian A. Gueymard, Solar Consulting Services (United States)

$4 \quad$ Solar Resources Modeling and Measurement II

Christian A. Gueymard, Solar Consulting Services (United States) 
Downloaded From: https://www.spiedigitallibrary.org/conference-proceedings-of-spie on 26 Apr 2023

Terms of Use: https://www.spiedigitallibrary.org/terms-of-use 


\section{Introduction}

The solar energy industry has been growing at a rate of $20 \%$ to $25 \%$ per year, and has generated $\$ 17.2$ billion (US) in revenues in 2007 . Production of high quality, reliable, and robust solar energy systems components for the market relies on the same fundamentals: careful measurements and good engineering models. Finding better ways to establish the quantity and quality of solar radiation resources depends upon good measurement technique and solar radiation models. New approaches to capturing, storing, and converting solar radiation into thermal and electrical energy begin with ideas, transition to theoretical models, and result in physical prototypes and finally production devices. Optical performance and properties measurements and models are crucial for advancing solar energy conversion system technologies.

The first two sessions on cells and systems modeling were chaired by Dr. Frank Vignola of the University of Oregon, manager of the university's Solar Monitoring Network. Topics included efficient characterization of photovoltaic cells in the production environment, anti-reflection, low concentration photovoltaics, nanostructured, dispersed, and composite selective coatings, quantum dot concentrators, and automatic parabolic concentrator focus control.

The two sessions on solar resource modeling and measurements were chaired by Dr. Christian Gueymard of Solar Consulting Services, internationally recognized author and solar modeling expert. Topics included infrared, spectral, and geometrical corrections in solar radiometry, fusion of ground and satellite estimates of solar radiation, optimal energy collection geometries, solar resource models for tilted surfaces, solar activity and atmospheric aerosols influences on solar resources, and solar resources over complex terrain.

Poster presentations and papers reporting on the measurement of the spectral content of flash solar simulators, laser based heliostat deflectometry, diffuse radiation over complex terrain, optimizing solar collection, and indoor characterization of photovoltaic modules rounded out the conference.

We thank the participants, the conference organizing committee, and the institutions sponsoring them, for the contributions resulting in an exceptional conference. The authors and program committee members represent the commitment of themselves and their respective institutions to building an economically stable future for our descendants, one new measurement, one new component, or one new model at a time.

Benjamin K. Tsai Daryl R. Myers 
Downloaded From: https://www.spiedigitallibrary.org/conference-proceedings-of-spie on 26 Apr 2023

Terms of Use: https://www.spiedigitallibrary.org/terms-of-use 